Article

\title{
Optimization of Water Consumption Distribution Based on Crop Suitability in the Middle Reaches of Heihe River
}

\author{
Liuyue He, Sufen Wang *, Congcong Peng and Qian Tan
}

Center for Agricultural Water Research in China, China Agricultural University, Beijing 100083, China; Hely2018@163.com (L.H.); pengcongcong1016@163.com (C.P.); qian_tan@cau.edu.cn (Q.T.)

* Correspondence: wangsuf@cau.edu.cn; Tel.: +86-10-6273-8548

Received: 9 May 2018; Accepted: 13 June 2018; Published: 21 June 2018

\begin{abstract}
Optimizing regional crop water consumption is considered to be a significant approach for increasing yields and reducing water consumption. This paper proposes a single-objective linear programming model which couples the distributed water consumption model with crop suitability. The impacts of meteorological, topographic, and soil factors were taken into account in both the distributed water consumption model and the crop suitability. The developed model was applied to a real case study in the middle reaches of Heihe River basin, in the northwest of China. In the optimization model, the net benefit which combined the water consumption with crop suitability was regarded as the objective function, while the limits on available water and planting area were set as the constraints. Optimal results regarding crop distribution and water consumption were generated for dry, normal, and wet hydrological years. Two optimization strategies were analyzed, including one with a fixed area of each crop and the other with a fixed total planting area. Economic analyses showed that net income under both optimization strategies increased by $31 \%$ and $33 \%$, respectively. Although water consumption increased slightly in both optimization scenarios, the unit water income and unit area income were much higher than in the pre-optimization conditions. The obtained results are valuable for supporting the adjustment of planting patterns and the identification of desired plans for sustainable irrigation water allocation.
\end{abstract}

Keywords: spatiotemporal variability; distributed model; crop suitability; planting pattern

\section{Introduction}

In recent decades, water scarcity has been more serious due to human-induced environment changes. For example, the advancement of industrialization has been sharply reducing water quantity and significantly deteriorating water quality, and population growth has caused a fast rise in water demand [1]. In the last decade, in the middle reaches of Heihe River, the dramatic increase in cultivated area and irrigation area has led to a dramatic increase in agricultural water consumption [2]. Declining water availability and growing water demand have intensified water competition among sectors, resulting in enormous risks in food security. Agriculture is the largest consumer of water in most countries, especially in China. Agricultural water accounts for $62.4 \%$ of total water use, which is much higher than industrial, domestic, and ecological water use [3]. Due to intensive agricultural production in Heihe River basin, agricultural irrigation occupies approximately $90 \%$ of the local total water consumption [4]. The conflict between food demand and limited water resources has been an acute issue in this area. Therefore, proper agricultural water management is crucial in achieving food security and sustaining livelihoods. Crop water consumption accounts for a large proportion of agricultural water. With the development of science, agricultural water can be rationally allocated 
to reduce unnecessary water consumption through various methods, such as the optimization of water-land combinations under various scales. Therefore, optimization models can be an effective tool for crop water management [4-6].

In order to figure out how to optimize agricultural planting patterns and achieve water-saving potential from cultivation, an increasing number of scholars have carried out studies on the optimization of planting patterns under various constraints related to water resources [7]. For example, in 2012, the discrete particle swarm optimization (DPSO) algorithm was applied to optimize cropping areas and irrigation water allocation [8]. Apart from the DPSO, many other mathematical algorithms such as linear programming (LP), nonlinear programming (NLP), dynamic programming (DP), genetic algorithm (GA), and simulated annealing arithmetic (SAA) have been used to solve specific optimization problems in the last decade [9-11]. In 2016, an interval linear fractional irrigation water allocation (ILFIWA) model was developed to address uncertainty in an irrigation system through coupling interval parameter programming (IPP) with linear fractional programming (LFP) [12]. The past reviews on optimization models are mainly focused on the following sections: irrigation management, crop pattern adjustment, and water resource allocation, etc. $[13,14]$. The past studies on water resource allocation mainly concentrate on water distribution during crop growth or water distribution among different crops. However, they are achieved by a top-down quantitative water allocation method [15-17], which cannot make corresponding water adjustments according to crop water consumption. In addition, most previous studies on crop planting patterns only change the cropping areas [18]. In fact, when the available agricultural water is drastically reduced, the really important issues for authorities and farmers are what kind of crops should be planted, and over how much area and where should they be planted to ensure the maximum economic benefits. Therefore, once the water consumption distribution of regional crops can be obtained, planting patterns can be adjusted by optimizing crop water consumption.

However, crop water consumption is affected by various factors, such as climate, topography, and soil, which makes it difficult to calculate under different temporal and spatial scales $[19,20]$. For this reason, some studies began to focus on the spatiotemporal variability in water consumption. The net radiation and Normalized Difference Vegetation Index (NDVI) were found to be the driving factors of the temporal and spatial variations in crop water use, and a number of empirical models were established accordingly in reported areas [21]. However, due to the inconsistency in driving factors within a region, there were few studies on estimating regional crop water consumption through the driving factors. Accordingly, some researchers began to consider the spatial and temporal scales separately in their studies [22]. For example, a software program was developed to maximize the gross margin by optimizing cropping patterns under the boundary conditions of limited water (temporal scale) and available land (spatial scale). A number of optimization models [23] and decision support methods [24] were also developed to optimize the allocation of agricultural water at a certain time or spatial scale. The characteristics of spatiotemporal changes suitable for the growth of important crops are gradually being emphasized in future climate scenarios [25]. Other studies which related to the costs of critical infrastructure operation [26,27] and forecasts [28,29] provide the possibility of optimizing scenarios. The above studies on temporal and spatial variations have inspired us with new ways to combine regional water consumption with mathematical optimization. The temporal and spatial variability of meteorological, soil, and terrain factors has great impacts on crop growth and water consumption, but it was not taken into account in the previous cropping optimization. In addition to affecting crop water consumption, spatiotemporal variability directly affects crop growth. In ecological evaluation, crop suitability (CS) has been an important indicator to evaluate the status of cultivated land and the growth environment for crops, such as the climate, topography, and soil $[30,31]$. One of the most important strategies for improving water use efficiency in agriculture is the correct choice of cropping systems adapted to the climatic and pedological conditions of the site [32]. Combing crop suitability with crop water consumption can effectively reflect the influence of spatiotemporal factors on the crop growth. However, it was not reported in the existing literature. 
Therefore, the aim of this study is to develop a crop water consumption optimization model based on crop suitability to optimize water use distribution. The benefits of the developed model include (1) reflecting the soil, topographic, and climatic factors on crop water consumption; and (2) intuitively displaying the distribution of water consumption and crop planting on any grid cell. This intuitive display of the optimization distribution of planting patterns and water consumption has never been seen in previous studies, and will provide new ideas for future crop optimization. This model is then applied to a real case study of crop optimization in the middle reaches of Heihe River basin, China. The generated crop planting pattern will demonstrate the feasibility and applicability of the developed model, and it can be helpful for managers to determine crop water consumption at various grid cells with different water availability. The method of construction of the optimization model is not limited to any area and can therefore be used anywhere.

\section{Materials and Methods}

This study built a regional optimization model by combining the distributed crop water consumption model with the evaluation results of crop suitability. It can be an effective way to optimize regional crop water consumption on time and spatial scales. The methodology includes the following steps: (1) combine the water consumption throughout the course of crop growth (temporal scale) with the spatial distribution of crop water consumption (spatial scale) to obtain a distributed crop water consumption model; (2) calculate crop suitability (CS) based on the ecological niche model and the main growth influence factors; (3) take the economic benefits as the objective function of the optimization model, built from the distributed water consumption model and crop suitability, with the crop species as the decision variables and the cultivated area and available water as the constraints; (4) adjust crop planting spatial distribution according to water availability in different hydrological years (Dry, Normal, and Wet years) through the established optimization model; and (5) analyze the economic benefits and water consumption indicators under two optimization scenarios (one with a fixed area of each crop, and the other with a fixed total area). Figure 1 shows the general framework of the study model. In this study, wheat, maize, and seed corn, which are the main crops in the middle reaches of the Heihe River, have been selected as the study subjects. Previous studies have shown that there is a small difference in water consumption during the whole growth period between seed corn and field corn [33]. In addition, there are few studies on the suitability of crops. Therefore, in this study, the water consumption and crop suitability of maize are considered to be equivalent to those of seed corn. However, the economic benefits are still calculated separately in the optimization model. This is because there is a big difference between maize and seed corn in the market price, and the minimum planting areas of field corn and seed corn are restricted by local policies.

The purpose of this section is to introduce the development procedures of the distributed crop water consumption model, the crop suitability model, and the optimization model. 


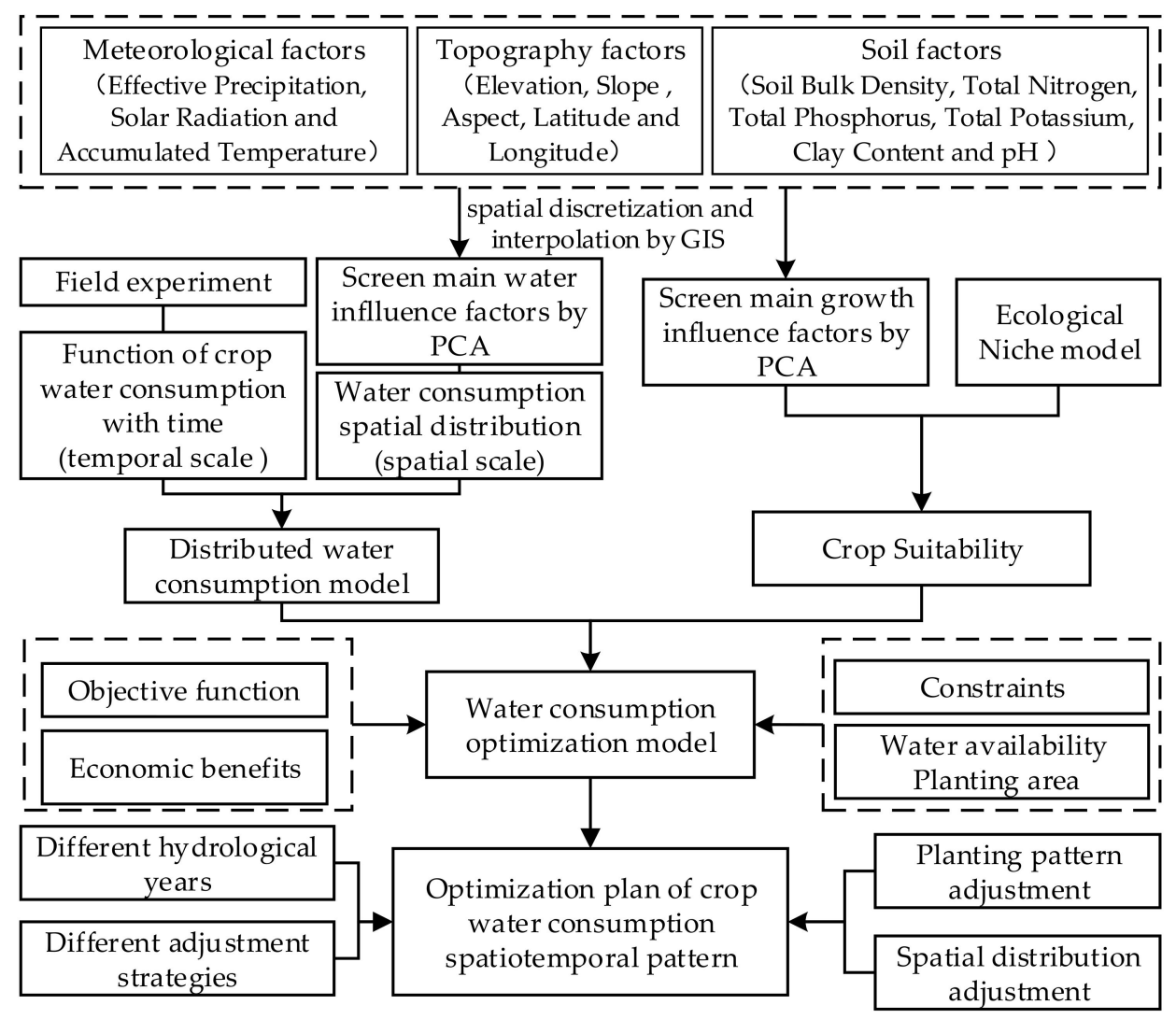

Figure 1. Framework of the study. Note: PCA means the method of principal component analysis; GIS means geographical information system.

\subsection{The Distributed Crop Water Consumption Model}

(a) Calculation of $E T_{c}$ for Each Weather Station

Based on the data (from 1961 to 2010) from ten weather stations which are distributed in the Heihe River basin, we calculated the crop water consumption $\left(E T_{c}\right)$ by the crop coefficient method:

$$
E T_{c}=E T_{0} \times K_{c}
$$

where $E T_{c}$ is the crop evapotranspiration $(\mathrm{mm} / \mathrm{d}) ; E T_{0}$ is the reference evapotranspiration, calculated according to the Food Agriculture Organization (FAO) Penman-Monteith equation [34]; and $K_{c}$ is the crop coefficient, which is calculated according to experimental results from 1989 to 1991 [35] (Table 1). The test site was in the Zhangye Irrigation Experiment Station of the Gansu Academy of Agricultural Sciences, which is located in the middle reaches of Heihe River. Therefore, these crop coefficients were calculated on all weather stations.

Table 1. $\mathrm{K}_{\mathrm{c}}$ in each month of the growth period.

\begin{tabular}{lccccccc}
\hline & March & April & May & June & July & August & September \\
\hline Wheat & 0.594 & 0.812 & 1.336 & 1.665 & 1.739 & $/$ & $/$ \\
Maize & $/$ & 0.418 & 0.483 & 0.723 & 1.211 & 1.377 & 1.562 \\
\hline
\end{tabular}

(b) Interpolation of $E T_{c}$ and Meteorological Variables in the Entire Heihe River Basin

The $E T_{c}$ and the meteorological variables of the weather stations were interpolated to obtain values for each cell with a size of $900 \mathrm{~m} \times 900 \mathrm{~m}$, by using the multiple linear regression (MLR) plus inverse 
distance weighting (IDW) method [36] in ArcGIS 10.0 platform which was developed by Environmental Systems Research Institute, United States. First, we established a regression relationship between the data and the latitude $(\varphi)$, longitude $(\lambda)$, and elevation $(Z)$ of the weather station. Then, the regression formula was used to calculate the values at each grid cell. Afterwards, the residual values of weather stations obtained by regression were interpolated by IDW to obtain the residual values of each grid cell. Finally, we superimposed the regressed calculation results and interpolated residuals of cells to get the final values. After obtaining the meteorological data of the entire Heihe River Basin, the mask extraction tool in geographical information system (GIS) was used to extract the data values of the cultivated land in the middle reaches of the Heihe River.

(c) Screening of the Main Influencing Factors of Crop Water Consumption

The main influencing factors for crop water consumption were extracted from the meteorological variables (effective precipitation $\left(P_{e}\right)$, solar radiation $\left(R_{a}\right)$, accumulated temperature $\left(T_{a}\right)$, and $\left.E T_{0}\right)$, soil properties (soil bulk density $\left(\rho_{b}\right)$ ) and topographical characteristics (elevation $(Z)$, slope $(S)$, and aspect $(A)$ obtained from the Digital Elevation Model (DEM)) by using Principal Component Analysis (PCA) [37]. Multivariate linear regression analysis was used to establish the spatial relationship between crop water consumption and the selected influencing factors:

$$
E T_{c i j}=F(c)_{i j}=k+a F_{a i j}+b F_{b i j}+\ldots+n F_{n i j}
$$

where $j$ is the cell $(j=1,2, \ldots, \mathrm{m})$, and $\mathrm{m}$ is the number of cells; $E T_{c j}$ is the evapotranspiration in cell $j(\mathrm{~mm} / \mathrm{d})$. The study area is divided into 1995 cells and each cell must have only one crop $(\mathrm{m}=1995)$. $k, a, b, n$ are the constant and the regression coefficients; $F a, F b$, and $F n$ are the selected influencing factors. $F(c)_{i j}$ is the relationship between crop water consumption and impact factors.

(d) Obtention of the Distributed Crop Water Consumption Model over Time

We fit crop water use data obtained from the field experiments [35] to get the function of crop water consumption over time as a quadratic function (Equation (3)):

$$
E T_{\mathcal{c t}}=f(t)_{i}
$$

where $E T_{c t}$ is the crop water consumption at time $t(\mathrm{~mm} / \mathrm{d}) ; t$ is the number of days from the beginning (d); $i$ is the crop type $(1,2, \ldots, \mathrm{I})$, and $\mathrm{I}=3$ in this study; and $f(t)_{i}$ is the relationship between crop water consumption and time.

We combine Equations (2) and (3) to get a distributed crop water consumption model over time:

$$
E T_{c j t}=\left(k+a F_{a j}+b F_{b j}+\ldots+n F_{n j}\right) \times \frac{E T_{c t}}{\sum_{t=1}^{T} E T_{c t}}
$$

where $E T_{c j t}$ is the crop water consumption in cell $j$ at time $t(\mathrm{~mm} / \mathrm{d})$; and $T$ is the total days of growth (d).

(e) Consideration of Water Deficit in Distributed Crop Water Consumption Model

Considering that the actual water stress often occurs for most crops during their growth, especially in arid and semi-arid regions, Equation (4) is amended as follows:

$$
E T_{a j t}=E T_{c j t} \times K_{s j t}=\left(k+a F_{a j}+b F_{b j}+\cdots+n F_{n j}\right) \times \frac{E T_{c t}}{\sum_{t=1}^{T} E T_{c t}} \times K_{s j t}
$$


where $E T_{a j t}$ is the actual crop water consumption in cell $j$ at time $t(\mathrm{~mm} / \mathrm{d}) . K_{s}$ is the water stress coefficient in each grid for crops and can be written as

$$
K_{s}= \begin{cases}1 & N D V I>s t a N D V I \\ N D V I / s t a N D V I & N D V I<s t a N D V I\end{cases}
$$

where NDVI is normalized difference vegetation index and staNDVI is the threshold of NDVI. According to the probability distribution of the NDVI value of all cells, the cumulative frequency of $90 \% \mathrm{NDVI}$ is set as the staNDVI. The NDVI was downloaded from the Heihe Planning Data Management Center [38]. The data has a high temporal resolution ( 5 days) and spatial resolution $(1 \mathrm{~km})$. The verification results of the data in farmland and forest areas in the middle reaches of the Heihe River indicate that there is a good agreement with the measured data on the ground (RMSE $=0.105)$ [39].

\subsection{The Crop Suitability}

In this paper, the crop suitability is used to reflect the suitability of the crop to the environment.

$$
C S=\sum_{k=1}^{n} S_{k} \cdot W_{k}
$$

In Equation (7), CS is the crop suitability index; $S_{k}$ is the niche suitability of crop habitat condition $k, k \in[1, \mathrm{n}]$, where $n$ is the number of influencing factors; and $W_{k}$ is the weight value of habitat factors, determined by the PCA. The evaluation factors of crop suitability include soil factors (total nitrogen, total phosphorus, total potassium, clay content, and $\mathrm{pH}$ value), meteorological factors (rainfall, accumulated temperature, $\mathrm{ET}_{\mathrm{c}}$ ), and topographic factors (elevation, slope, aspect). The larger the $C S$ is, the better the suitability is.

According to the ecological niche suitability model [40], habitat condition is divided into three categories: "the larger the better", "appropriate interval", and "the smaller the better". $S_{k}$ is expressed as different equations when referring to different habitat conditions.

The first category is for the "the larger the better" type, such as organic matter, total nitrogen, total phosphorus, and total potassium content. In this case, the larger the value of the environmental factor, the better the suitability is, and $S_{k}$ is expressed as Equation (8).

$$
S_{k}=\left\{\begin{array}{cc}
0 & X_{k} \leq D_{k \min } \\
X_{k} / D_{\text {kopt }} & D_{k \min }<X_{k}<D_{\text {kopt }} \\
1 & X_{k} \geq D_{\text {kopt }}
\end{array}\right.
$$

The second category is environmental factors of which crops require a certain range. Too much or too little is not conducive to crop growth, such as for sand content and $\mathrm{pH}$ value. The $S_{k}$ is calculated by Equation (9).

$$
S_{k}=\left\{\begin{array}{cc}
0 & X_{k} \leq D_{k \min } \quad \text { or } \quad X_{k} \geq D_{k \max } \\
X_{k} / D_{k o p t} & D_{k \min }<X_{k}<D_{k o p t} \\
1 & D_{k o p t}<X_{k}<D_{k \max }
\end{array}\right.
$$

The third category is for the "the smaller the better" type, such as slope. $S_{k}$ can be given by

$$
S_{k}=\left\{\begin{array}{cc}
1 & X_{k} \leq D_{k \min } \\
1-\left(D_{k \max }-X_{k}\right) /\left(D_{k \max }-D_{k \min }\right) & D_{k \min }<X_{k}<D_{k o p t} \\
\left(D_{k \max }-X_{k}\right) /\left(D_{k \max }-D_{k o p t}\right) & X_{k} \geq D_{k \max }
\end{array}\right.
$$

where $X_{k}$ is the real niche of $k$ in evaluation cells; $D_{k \min }$ and $D_{k \max }$ are the minimum and maximum of the real niche of factor $k$, respectively; and $D_{k \text { opt }}$ is the ideal niche of factor $k$. 


\subsection{The Optimization Model}

Although a large number of studies have shown that too much or too little soil moisture can inhibit crop growth and reduce crop yields [41,42], few crops are suppressed in arid and semi-arid areas due to too much soil moisture because of the low rainfall during the growth season. Thus, the crop water production function between crop water consumption and yield can also be considered as a linear relationship. Based on statistical data, crop yields can be amended using the crop water consumption and crop suitability models from Sections 2.1 and 2.2. In this paper, optimization criteria are set as follows: (1) for the same crop in different locations, the greater the multiplied value of ET and CS is, the better the suitability for crop growth is, and the greater the crop yield and economic efficiency are; and (2) for the same cell, the crop with the highest net benefits has the top priority for planting. In addition, taking the unilateral water benefits of the region as the final goal in the optimization model can effectively avoid waste of water and reduced economic benefit. The optimization model can thus be formulated as follows:

Objective function:

$$
\max f=\sum_{i=1}^{I} \sum_{j=1}^{m}\left[\left(\frac{E T_{a i j} \times C S_{i j}}{\overline{E T_{a i j} \times C S_{i j}}} \times v_{i j} y_{i j}-c_{i j}\right) / E T_{a i j}\right] \times x_{i j}
$$

where $x_{i j}$ is the decision variable; $f$ is the net income $(\$ / \mathrm{ha} / \mathrm{mm}) ; v_{i j}$ is the unit price of the crop (i) in the cell ( $(j)(\$ / \mathrm{kg}) ; y_{i j}$ is the yield ( $\left.\mathrm{kg} / \mathrm{ha}\right) ; C S_{i j}$ is the crop suitability evaluation value; $c_{i j}$ is the cost of crops, include planting costs and labor costs (\$/ha); and $\overline{E T_{a i j} \times C S_{i j}}$ is the mean of $E T_{a i j} \times C S_{i j}$.

Constraints:

(1) Water availability constraint. The sum of water allocated to all cells must not exceed the total agricultural available water. This constraint can be written as

$$
\sum_{i=1}^{I} \sum_{j=1}^{m} m_{i j} x_{i j} \times a \times 10^{-3} \leq \lambda Q
$$

where $m_{i j}$ is the amount of irrigation water $(\mathrm{mm})$, which is obtained by deducting effective rainfall from $E T_{a}$ for crop growth; $\lambda$ is the irrigation water use efficiency; $Q$ is the available agricultural water $\left(\mathrm{m}^{3}\right)$; and $a$ is the area of the cell $\left(\mathrm{m}^{2}\right)$.

(2) Planting area constraint. The planting area of each crop must exceed the minimum value during the ten-year period from 2001 to 2010 to ensure local food security. Simultaneously, the sum of all crop areas is controlled within the total area. The constraint can be expressed as

$$
\begin{aligned}
& a_{i \min } \leq \sum_{j=1}^{m} x_{i j} \times a \\
& \sum_{i=1}^{I} \sum_{j=1}^{m} x_{i j} \times a \leq b
\end{aligned}
$$

where $a_{\min }$ is the lower limit of planting area (ha) and $b$ is the total area in this study area (ha).

(3) Decision variables constraint. In this model, the decision variables are limited by the following equation:

$$
\sum_{i=1}^{I} x_{i j}=1 \text {, and } x_{i j}=1 \text { or } 0 .
$$

\subsection{Study Area and Data}

The study area is located in the middle reaches of Heihe River basin $\left(38^{\circ} 39 /-39^{\circ} 59 / \mathrm{N}\right.$, $\left.98^{\circ} 58 /-100^{\circ} 51 / \mathrm{E}\right)$, China, including Ganzhou District, Linze County, and Gaotai County (Figure 2). 
From the 30 year averages of weather variables, the study area presents a continental dry climate, strong solar radiation and evaporation, and reduced rainfall [43]. The middle reaches are the main agricultural production area of the Heihe River Basin, which involves $40 \%$ of the whole river basin's population, $60 \%$ of the total crop planting area, and $70 \%$ of the total water resource consumption from the Heihe main stream [44]. Moreover, a large amount of agricultural irrigation water in the middle reaches squeeze ecological water use in the lower reaches, giving rise to destruction of the ecological environment. Therefore, it is significant to adjust crop area planning and promote water resource allocation in the middle reaches of Heihe River basin.

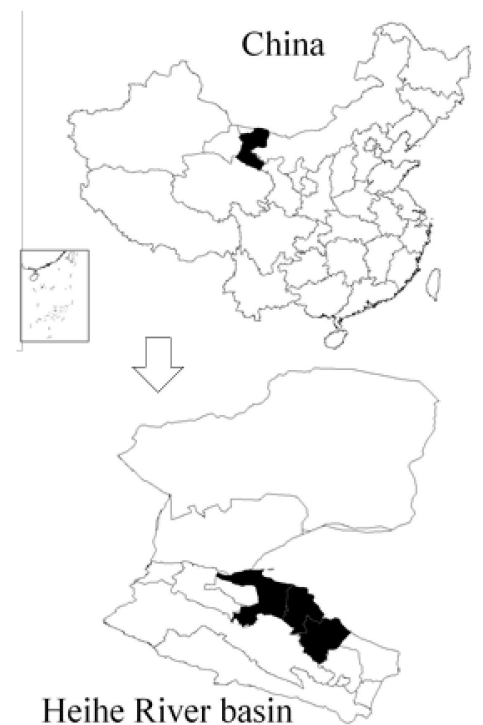

Heihe River basin

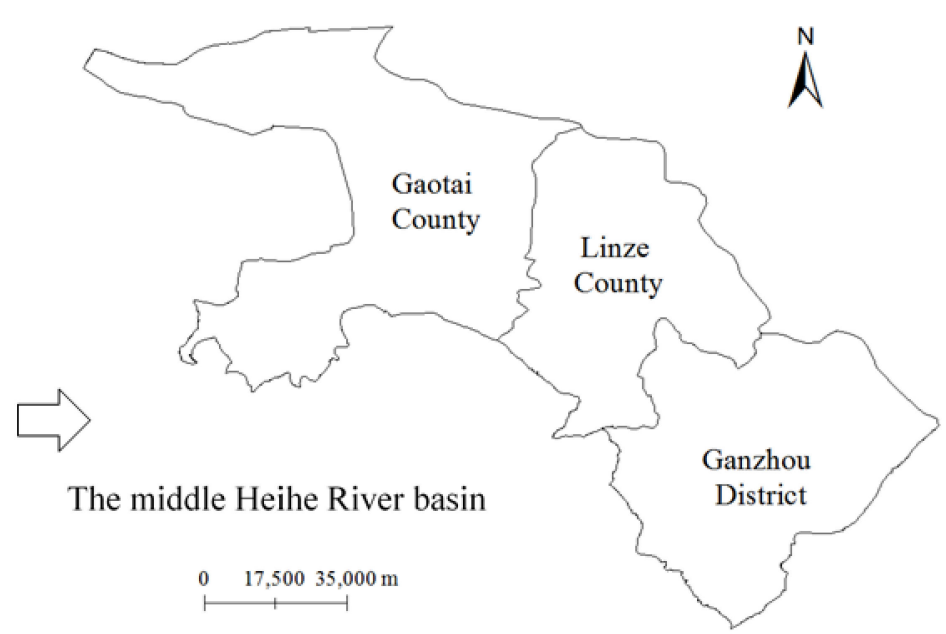

Figure 2. The study area.

The study area is characterized by relatively higher altitude in the south and lower altitude in the north, with elevations ranging from $1235 \mathrm{~m}$ to $3634 \mathrm{~m}$. The annual mean precipitation is only 60 280 mm which is far less than the average annual evaporation of 2000 3500 mm. Besides this, the rainfall is unevenly distributed during the year and $75 \%$ of the precipitation is concentrated in June to September. According to the Harmonized World Soil Database, in the study area, the soil texture also changes from clay loam soil in the southeast to sticky salt sand in the northwest. As affected by the deposition of terrain water, the soil particles are coarse in the south and fine in the north. The content of organic matter in the south can reach up to $8 \%$, and the content of organic matter in most areas in the north is less than $1 \%$. The total nitrogen content varies from 0 to $0.4 \%$ throughout the region and becomes lower from the south to the north. However, more than $90 \%$ of the area is less than $0.1 \%$, which is not very suitable for crop growth if not changed by human measures. The total phosphorus content in the whole area is less than $0.08 \%$, which is much less than the crop-suitable value of $0.17 \%$ [43]. In contrast, the total potassium content of the area is high, varying from $1.5 \%$ to $2 \%$. In sum, the overall nutrient status of the study area features insufficiency in nitrogen and phosphorus and surplus of potassium. According to the Land-Use and Land-Cover Change (LUCC) classification results (shown in Figure 3), more than half of the land in the middle reaches of Heihe River is bare land. Next to that are the cropland and grassland, accounting for $24 \%$ and $15 \%$ of the land area, respectively. The woodland area occupies the smallest area, taking up only $1.5 \%$ of the total. The vegetation coverage in the south is denser than that in the north.

The study area is divided into 1995 cells with a size of $900 \mathrm{~m} \times 900 \mathrm{~m}$. The year 2014 was chosen as the research year because of information sufficiency. Table 2 shows the relevant inputs of the optimization model for crops in 2014. These data include yield (y), cost price (c), market price (v), and minimum planting area $\left(a_{\min }\right)$ of crops; and irrigation water use efficiency $(\lambda)$. The irrigation water use efficiency $(\lambda)$ 
selected in this paper represents the irrigation efficiency of the entire region, taking into account the canal irrigation water efficiency and the field irrigation water efficiency. All these came from the statistical data (e.g., Gansu agricultural products bazaars prices in 2014, Analysis on Grain Production of Summer and Autumn in Zhangye and Statistical Yearbook in Zhangye in 2005 2014). The minimum planting area of the crop from 2005 to 2014 is treated as $a_{\mathrm{min}}$. Table 3 shows the agricultural available water and rainfall in dry, normal, and wet years, with the guarantee rate being $80 \%, 50 \%, 20 \%$, respectively. Different hydrological years are divided according to the Pearson-III (PIII) frequency curve which was calculated from the 50 years of meteorological data from 1961 to 2010. The available agricultural water came from The Heihe Water Dispatch Workbook, and the effective rainfall during the crop growth period was calculated from the annual mean value from 1961 to 2010. The growth period of maize is from 15 April to 5 September and that of wheat is from 15 March to 25 July.

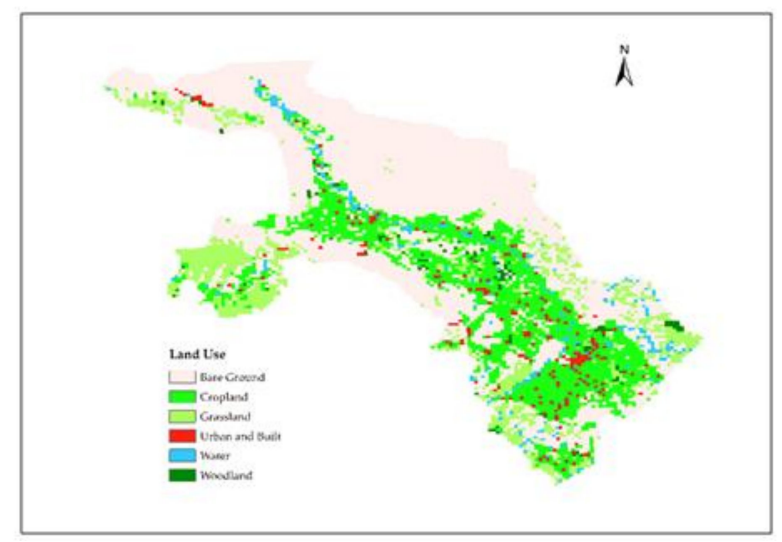

Figure 3. The land use of the middle reaches of Heihe River.

Table 2. Crop information of the optimization model.

\begin{tabular}{|c|c|c|c|c|c|}
\hline Item & $\begin{array}{l}\text { Yield (y) } \\
\text { (kg/ha) }\end{array}$ & $\begin{array}{l}\text { Cost Price } \\
\text { (c) }(\$ / \mathrm{ha})\end{array}$ & $\begin{array}{l}\text { Market Price } \\
\text { (v) (\$/kg) }\end{array}$ & $\begin{array}{l}\text { Minimum Planting } \\
\text { Area }\left(a_{\min }\right)\left(10^{4} \mathrm{ha}\right)\end{array}$ & $\begin{array}{c}\text { Irrigation Water } \\
\text { Use Efficiency }(\lambda)\end{array}$ \\
\hline Wheat & 6373.5 & 888.46 & 0.38 & 1.2 & \multirow{3}{*}{0.53} \\
\hline Maize & 8196 & 888.46 & 0.33 & 1.0 & \\
\hline Seed Corn & 8196 & 1776.92 & 0.62 & 6.4 & \\
\hline
\end{tabular}

Table 3. The basic data of different hydrological years.

\begin{tabular}{cccc}
\hline Item & Dry Year & Normal Year & Wet Year \\
\hline Agricultural available water $\left(10^{8} \mathrm{~m}^{3}\right)$ & 9.39 & 9.92 & 10.45 \\
Effective rainfall in wheat growth period $(\mathrm{mm})$ & 40.0 & 64.3 & 80.1 \\
Effective rainfall in maize growth period $(\mathrm{mm})$ & 82.6 & 102.8 & 125.5 \\
\hline
\end{tabular}

\section{Results and Discussions}

\subsection{Distributed Crop Water Consumption Model}

The crop water consumption of maize $\left(F(c)_{M}\right)$ and wheat $\left(F(c)_{W}\right)$ calculated by Equation (2) can be obtained as follows:

$$
\begin{gathered}
F(\mathrm{c})_{M}=410.54+0.078 Z+0.386 \rho_{b}+0.049 T_{a}-0.399 P_{e} \\
F(\mathrm{c})_{W}=326.884+0.117 Z-1.693 \rho_{b}+0.137 T_{a}-0.692 P_{e} .
\end{gathered}
$$


Through linear regression analysis of field experiment data, we can get the water consumption changes of maize $\left(f(t)_{M}\right)$ and wheat $\left(f(t)_{W}\right)$ with time $t$ throughout the growth period:

$$
\begin{gathered}
f(t)_{M}=-0.00034 t^{2}+0.083 t+0.4245 \\
f(t)_{W}=-0.00055 t^{2}+0.13308 t+0.3843
\end{gathered}
$$

where $t$ is the number of days from emergence.

Equation (5), which reflects the temporal and spatial variation of crop water consumption, can be achieved as

$$
\begin{gathered}
E T_{a M}=\left(410.54+0.078 Z+0.386 \rho_{b}+0.049 T-0.399 P_{e}\right) \times K_{\mathrm{S}} \times \frac{-0.00034 t^{2}+0.083 t+0.4245}{\sum_{t=1}^{T}\left(-0.00034 t^{2}+0.083 t+0.4245\right)} \\
E T_{a W}=\left(326.884+0.117 Z-1.693 \rho_{b}+0.137 T-0.692 P_{e}\right) \times \mathrm{K}_{\mathrm{S}} \times \frac{-0.00055 t^{2}+0.13308 t+0.3843}{\sum_{t=1}^{T}\left(-0.00055 t^{2}+0.13308 t+0.3843\right)}
\end{gathered}
$$

where $T$ is the whole growth period in days.

The simulated values of $E T_{a}$ during the whole growing season (the growth period days of wheat and maize are 133 and 144, respectively) directly obtained by the distributed water consumption model (Equation (20) and (21)) are shown in Figure 4, and are in agreement with the spatial interpolated values. The determination coefficient $\left(\mathrm{R}^{2}\right)$, mean absolute error (MAE), and root mean squared error (RMSE) for wheat are $0.58,72.87 \mathrm{~mm}$, and $52.55 \mathrm{~mm}$. Those values for maize are $0.59,82.61 \mathrm{~mm}$, and $68.47 \mathrm{~mm}$. The water consumption of wheat ranges from $297 \mathrm{~mm}$ to $733 \mathrm{~mm}$ and that of maize ranges from $235 \mathrm{~mm}$ to $626 \mathrm{~mm}$, which are consistent with the previous studies [45]. The lands in central Ganzhou and Linze have higher water consumption, where there are more densely planted than others whose crop water consumption is less, such as the west of Gaotai and the south of Ganzhou. One reason for this is that the low cultivation area is far from the center of the Heihe River and the amount of available water is less.

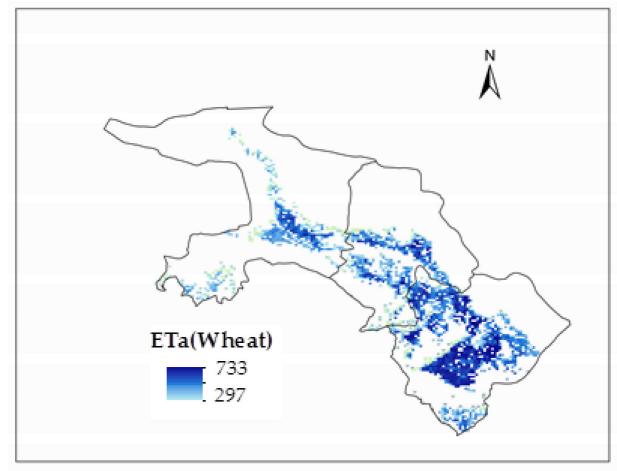

(a)

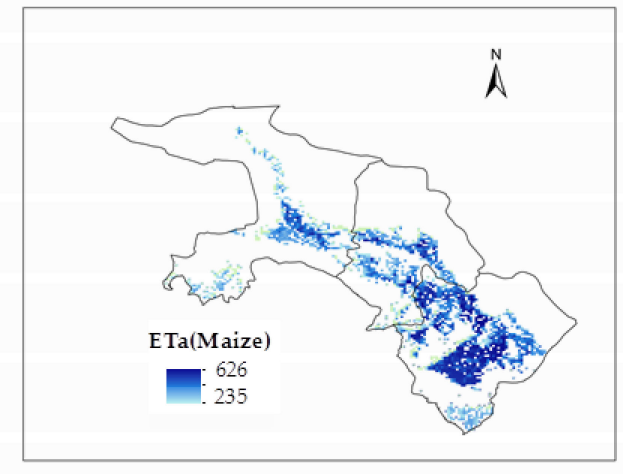

(b)

Figure 4. Distribution of water consumption simulation values for wheat (a) and maize (b).

\subsection{Crop Suitability}

The distribution of crop suitability can be obtained according to the niche model associated with each influencing factor. The suitability values of wheat and maize calculated from Equation (7) are shown in Figure 5. Similar to in other studies [46], the suitability values of wheat and maize are 0.495 0.907 and 0.496 0.915, respectively. Both the mean values are above 0.8. The area of land that is highly suitable for crops (CS $>0.72$ ) accounts for about $84.6 \%$ of the total in the study area, which means that most of the cultivated land can meet the requirements for growth of wheat and maize. The spatial distributions of the CS values of wheat and maize are basically consistent. Lower suitability values mainly occur in the areas with higher altitude, lower organic matter and nitrogen contents, 
limited rainfall, and higher accumulated temperature, such as southern Ganzhou and western Gaotai. Ganzhou has the highest CS average, followed by Linze and Gaotai. It can be observed that lower contents of organic matter, total nitrogen, and total phosphorus in soil lead to lower CS values. The CS values and crop yields could thus effectively increase through improving the physical and chemical properties of soil by fertilization.

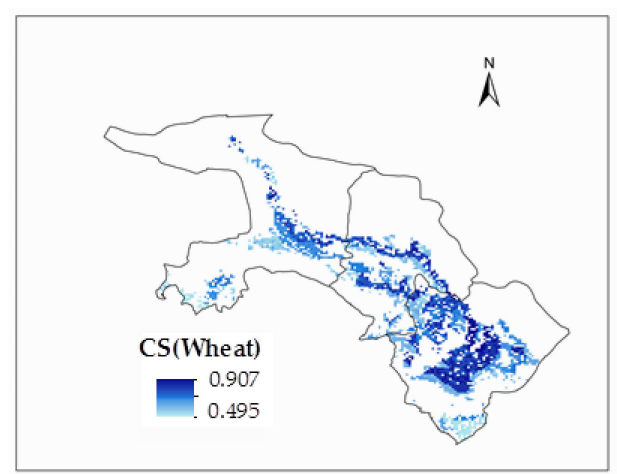

(a)

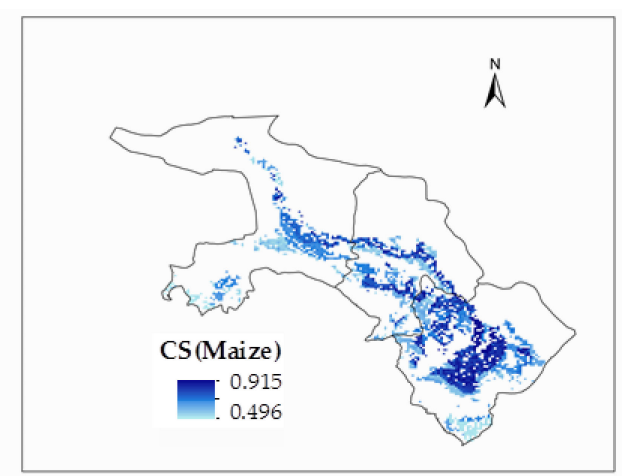

(b)

Figure 5. The suitability distribution of wheat (a) and maize (b).

\subsection{Optimization of Planting Pattern in Different Hydrological Years}

Figure 6 shows the respective distributions of planting patterns and water consumption in different hydrological years. The corresponding planting areas and economic benefits are shown in Table 4 . In each year, seed corn can be planted in a large area due to its high prices. The total water consumption of seed corn is also the highest among all the crops. Because of the significant economic benefits caused by seed production, the optimization model would allocate as much land and water resources as possible to the seed corn in accordance with the water supply in different hydrological years under the premise of satisfying food security and planting area constraints. Therefore, as the volume of available agricultural water increases, the planting area of seed corn increases significantly from $12.54 \times 10^{4}$ ha to $13.84 \times 10^{4}$ ha. In contrast, the total area of wheat and maize remain almost constant, and only the spatial distribution of crops changes. Although the planting area of seed corn and the water consumption respectively increase by $5.34 \%$ and $10.37 \%$ in normal and wet years, the net income per hectare which reflects the final benefit after deducting planting costs increases by only $4.90 \%$ and $9.71 \%$, respectively. In addition, considering the increase of the planting areas, the growth of the benefits per unit area is almost negligible. Further, with the increase of water consumption in wet years, the unilateral water benefits- the economic benefits per unit volume of water consumed-have been reduced by $0.85 \%$. The main reason for the smaller increase in economic efficiency per hectare is that the increased area of seed corn in the wet year is mainly located in the high-water-consumption area. However, the production is not proportional to the water consumption in this area. In normal years, the cells with lower water consumption are preferred for planting. Therefore, the maximum unilateral water benefits appear in normal years. Such results suggest that the increase in economic benefits brought by increased planting areas of seed corn in wet years is limited. The water use efficiency can be readily improved by adjusting the suitable planting areas of crops. In addition, the constraints on the maximal planting area of seed corn should also be integrated with governmental policy and demands. After all, corn is not supposed to be grown indefinitely. In summary, the planting pattern of local crops should be enriched. Other suitable crops or economic crops should be planted in high-water-consumption areas during wet years. Then, more crops should be planted in the areas where the crop water consumption is low. 
Table 4. The optimized results of planting patterns in different hydrological years.

\begin{tabular}{ccccccc}
\hline Index & Crops & Dry Year & Normal Year & $\%$ & Wet Year & $\%$ \\
\hline & Wheat & 1.20 & 1.20 & - & 1.20 & - \\
Area $\left(10^{4} \mathrm{ha}\right)$ & Maize & 1.00 & 1.00 & - & 1.00 & - \\
& Seed Corn & 12.54 & 13.21 & 5.34 & 13.84 & 10.37 \\
& Total & 14.74 & 15.41 & 4.54 & 16.04 & 8.82 \\
\hline & Wheat & 373.43 & 368.22 & -1.40 & 366.99 & -1.73 \\
Net Income $\left(10^{4} \$\right)$ & Maize & 691.03 & 691.03 & 0 & 691.03 & 0 \\
& Seed Corn & $45,805.25$ & $48,107.89$ & 5.03 & $50,363.88$ & 9.95 \\
& Total & $46,869.70$ & $49,167.14$ & 4.90 & $51,421.90$ & 9.71 \\
\hline Total water consumption $\left(10^{8} \mathrm{~m}^{3}\right)$ & 6.57 & 6.64 & 1.07 & 7.27 & 10.65 \\
Net income per unit area $(\$ / \mathrm{ha})$ & 3179.76 & 3190.60 & 0.34 & 3205.85 & 0.82 \\
Unilateral water benefits $\left(\$ / \mathrm{m}^{3}\right)$ & 0.71 & 0.74 & 3.66 & 0.71 & -0.86 \\
\hline
\end{tabular}

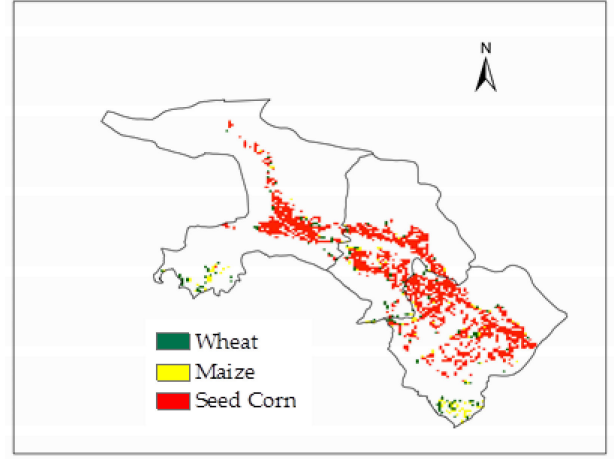

(a)

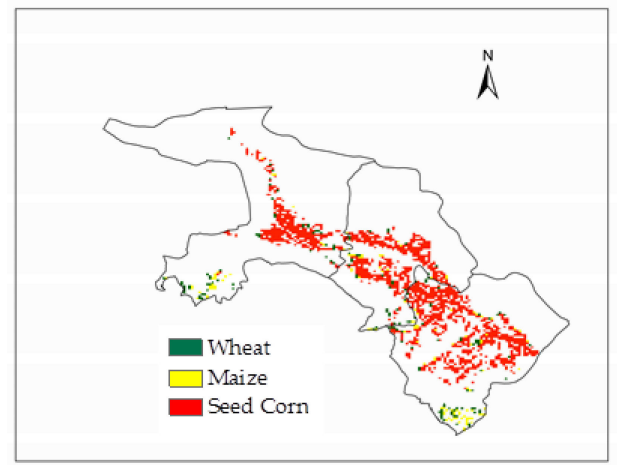

(c)

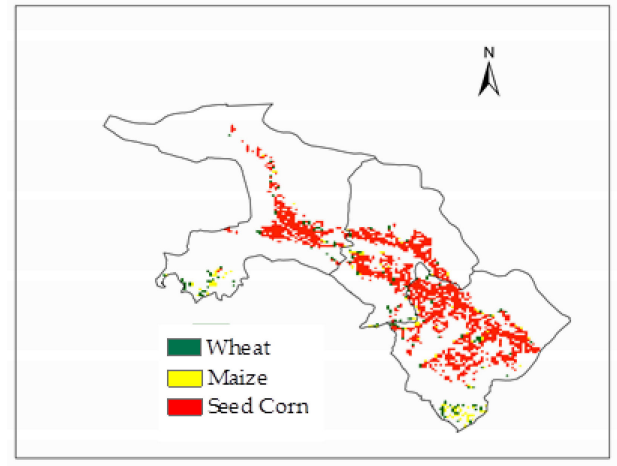

(e)

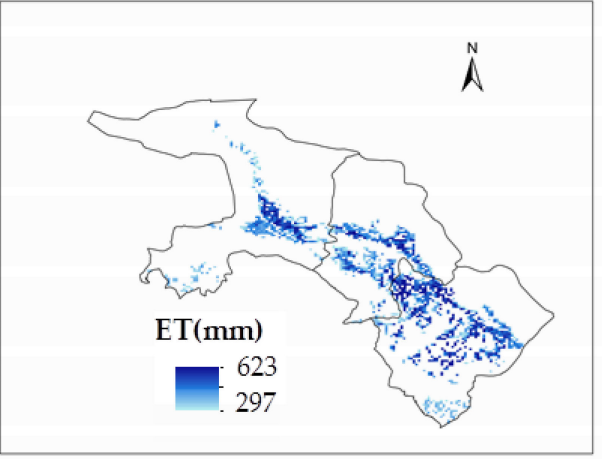

(b)

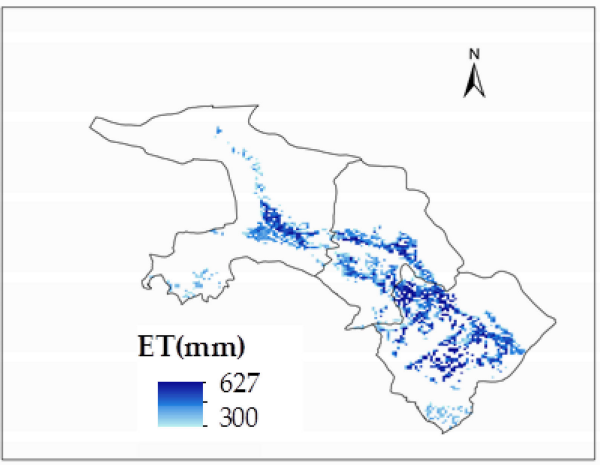

(d)

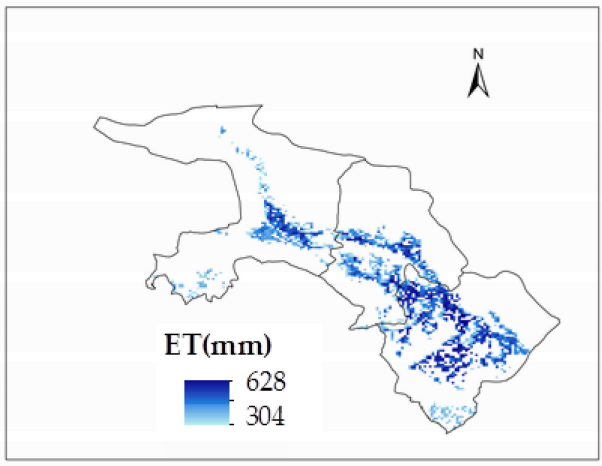

(f)

Figure 6. The optimized distributions of planting pattern (left) and water consumption (right) in different hydrological years: (a) planting pattern in dry year; (b) crop water consumption in dry year; (c) planting pattern in normal year; (d) crop water consumption in normal year; (e) planting pattern in wet year; (f) crop water consumption in wet year. 


\subsection{Comparative Advantages}

The economic benefits under the two strategies are shown in Table 5. The first strategy is to keep the planting area of each crop unchanged, while changing the spatial distribution (referred to as Strategy I). The second one is to keep the total acreage, while adjusting the planting area of each crop and its spatial distribution (Strategy II).

Table 5. The economic performance before and after optimization.

\begin{tabular}{ccccccc}
\hline Index & Crops & Present & Strategy I & $\mathbf{\%}$ & Strategy II & $\mathbf{\%}$ \\
\hline & Wheat & 1.29 & 1.29 & - & 1.20 & -6.97 \\
Area $\left(10^{4} \mathrm{ha}\right)$ & Maize & 1.20 & 1.20 & - & 1.00 & -16.67 \\
& Seed Corn & 6.40 & 6.40 & - & 6.69 & 4.53 \\
& Total & 8.89 & 8.89 & - & 8.89 & - \\
\hline & Wheat & 1947.83 & 2100.85 & 7.86 & 1941.71 & -0.31 \\
Net Income $\left(10^{4} \$\right)$ & Maize & 2187.03 & 2269.75 & 3.78 & 1855.96 & -15.14 \\
& Seed Corn & $20,907.32$ & $28,423.71$ & 35.95 & $29,498.38$ & 41.09 \\
& Total & $25,042.18$ & $32,794.31$ & 30.96 & $33,296.05$ & 32.96 \\
\hline Total water consumption $\left(10^{8} \mathrm{~m}^{3}\right)$ & 4.30 & 4.63 & 7.67 & 4.61 & 7.21 \\
Net income per unit area $\left(\$ / \mathrm{ha}^{3}\right)$ & 2816.89 & 3688.90 & 30.96 & 3745.34 & 32.96 \\
Unilateral water benefits $\left(\$ / \mathrm{m}^{3}\right)$ & 0.58 & 0.71 & 21.37 & 0.72 & 23.75 \\
\hline
\end{tabular}

After adjusting the distribution of current crops through Strategy I, an obvious improvement could be observed compared with the present situation. The net incomes of the three crops increased by $7.86 \%, 3.78 \%$, and $35.95 \%$, respectively. The total income increased by $30.96 \%$. The net benefits per unit area changed from 2816.89 \$/ha to 3688.90 \$/ha, which has the same growth rate as net income due to the unchanged cropping area. It is not difficult to find that the seed corn plays an important role in local crop production. In addition, though the total water consumption has slightly increased in Strategy I, the increase in total net incomes is much greater than that in the total water consumption. Thus, once the water consumption is considered, the increase in benefits is not as optimistic as the total net income. Therefore, through Strategy I, the unilateral water benefits have raised from $0.58 \$ / \mathrm{m}^{3}$ to $0.71 \$ / \mathrm{m}^{3}$, with an increase ratio of $21.37 \%$.

The second strategy shows another optimization scenario which not only adjusts the crop space layout but also the planting pattern in the case of fixed total area. As a result, the model allocates more area to seed corn which can bring about more benefits in general. The area of seed corn is increased by $41.09 \%$. Correspondingly, the areas of wheat and maize are reduced by $0.31 \%$ and $15.14 \%$, respectively. The results show that the overall economic benefits increase to 332.96 million dollars, the economic benefits per unit increase to $3745.34 \$ /$ ha, and the unilateral water benefits further increase to $0.72 \$ / \mathrm{m}^{3}$. Without doubt, the second optimization strategy outperforms the first strategy.

Compared with Strategy II, Strategy I results in not only a slight reduction in water consumption, but also an obvious increase in the overall economic benefits (especially the net incomes brought by seed corn). More specifically, an increase in overall economic efficiency is achieved along with reduced wheat and maize acreage. Nonetheless, this strategy may be more risky in certain circumstances. Although the minimum requirements for food safety related to wheat and maize can be ensured, there may be higher food security risks due to market volatility and policy changes. It is a clear fact that seed production is more profitable than the mass production of other crops. However, in most cases, it is unreasonable to improve agricultural water productivity merely by increasing the scale of seed production due to land insufficiency. Given this consideration, the unilateral water benefit of Strategy II has no practical significance. To sum up, the decision-makers may consider the following suggestions when adjusting the local crop planting pattern as per the optimization results: (1) increase the area of seed corn moderately according to related policies such as the corn reduction policy on the "Sickle Blend" area published by the Ministry of Agriculture [47]; and (2) try to reduce the inputs of 
food crops and increase economic crops on the premise of food security in high-water-consumption areas. In addition, decision-makers can also get optimized crop water consumption distributions at a given time through the model proposed in this paper.

\section{Conclusions}

A regional crop water consumption optimization model combining the distributed water consumption model with the crop suitability index has been established in this study, including the establishment of a distributed water consumption model as well as the optimization of agricultural water consumption distribution and planting patterns under different scenarios. As screened by PCA, the main water consumption factors in the distributed water consumption model are elevation, accumulated temperature, effective precipitation, $\mathrm{K}_{\mathrm{S}}$, and bulk density. The objective is to maximize the net income acquired from unit water and area. The decision variable is the species of crops planted in grids, and the constraints are the limits on cultivated area and available water. The developed optimization model is capable of (1) reasonably estimating crop water consumption during the growth period at any location with limited data; (2) adjusting the planting patterns according to demands; and (3) realistically reflecting the suitability for crop cultivation, water consumption, and socioeconomic policies.

The developed model was applied to a real study case in the middle reaches of Heihe River basin. The results for crop water consumption and planting pattern in grid cells were obtained under different hydrological years (dry year, normal year, and wet year with the guarantee rates being $80 \%$, $50 \%, 20 \%$, respectively) and two kinds of strategies. The first strategy is to keep the planting area of each crop unchanged, while changing the spatial distribution. The second one is to keep the total acreage, while adjusting the planting area of each crop and its spatial distribution. Economic analyses showed that net income under these optimization strategies increased by $31 \%$ and $33 \%$, respectively. Although water consumption increased slightly in both optimization scenarios, the unit water income and unit area income were much higher than before. Results show that the water use efficiency can be readily improved by adjusting the suitable planting areas of crops. It is suggested that the authorities take corresponding measures in the future to enrich the cultivation methods of local crops. Other appropriate crops and cash crops should be planted in high-consumption areas, especially when there is a large amount of available agricultural water in a wet year.

Incorporating the crop suitability index into the optimization model can also provide a new idea to other researchers. Analyses of different crop distribution policies corresponding to various scenarios could provide locals with more choices according to specific conditions. Specific planting patterns and irrigation regimes also need the input of managers/authorities responsible for irrigation water allocation. The study demonstrates the model's effectiveness and applicability in the optimization of crop planting patterns. However, there still exist some shortcomings in this study such as the inaccurate distribution of meteorological data caused by spatial interpolation of fewer weather stations. Increasing the credibility of the spatial weather data will be carried out in future work. In addition, the distributed crop water consumption model based on an empirical formula also brings some limitations to application. Future work will focus on the development of a distributed water consumption model to match more areas, the consideration of more crop types, and uncertainty in the optimization model.

Author Contributions: S.W. and C.P. analyzed and built the optimization model; L.H. and C.P. collected the related data and solved the model; L.H. and S.W. analyzed the results and wrote the paper; Q.T. modified this article.

Funding: This research was funded by the National Key Research and Development Plan (2016YFC0400207) and the National Natural Science Foundation of China (91425302, 51439006).

Acknowledgments: We are very grateful to Cold and Arid Regions Science Data Center at Lanzhou for providing the DEM and NDVI data.

Conflicts of Interest: The authors declare no conflict of interest. 


\section{References}

1. The United Nations World Water Development Report 2015-Water for Sustainable World (WWDR 2015). Available online: http:/ / www.unesco.org/new/en/natural-sciences/environment/water/wwap/wwdr/ 2015-water-for-a-sustainable-world/ (accessed on 18 August 2017).

2. Zou, M.Z.; Niu, J.; Kang, S.Z.; Li, X.L.; Lu, H.N. The contribution of human agricultural activities to increasing evapotranspiration is significantly greater than climate change effect over Heihe agricultural region. Sci. Rep. 2017, 7, 8805. [CrossRef] [PubMed]

3. The Ministry of Water Resources of the People's Republic of China. Available online: http:/ /www.mwr.gov. cn/sj/tjgb/szygb/201707/t20170711_955305.html/ (accessed on 15 August 2017).

4. Wagener, T.; Sivapalan, M.; Troch, P.A.; McGlynn, B.L.; Harman, C.J.; Gupta, H.V.; Kumar, P.; Rao, P.S.; Basu, N.B.; Wilson, J.S. The future of hydrology: An evolving science for a changing world. Water Resour. Res. 2010, 46, 1369-1377. [CrossRef]

5. Singh, A.; Panda, S.N. Development and application of an optimization model for the maximization of net agricultural return. Agric. Water Manag. 2012, 115, 267-275. [CrossRef]

6. Singh, A. Irrigation planning and management through optimization modeling. Water Resour. Manag. 2014, 28, 1-14. [CrossRef]

7. An, P.L.; Ren, W.; Liu, X.L.; Song, M.M.; Li, X.M. Adjustment and Optimization of the Cropping Systems under Water Constraint. Sustainability 2016, 8, 1207. [CrossRef]

8. Noory, H.; Liaghat, A.M.; Parsinejad, M.; Haddad, O.B. Optimizing irrigation water allocation and multicrop planning using discrete PSO algorithm. J. Irrig. Drain. Eng. 2016, 138, 437-444. [CrossRef]

9. Otieno, F.A.O.; Adeyemo, J.A. Strategies of differential evolution for optimum cropping pattern. Trends Appl. Sci. Res. 2010, 5, 1-15. [CrossRef]

10. Karamouz, M.; Zahraie, B.; Kerachian, R.; Eslami, A. Crop pattern and conjunctive use management: A case study. Irrig. Drain. 2008, 59, 161-173. [CrossRef]

11. Zhang, L.J.; Yin, X.A.; Xu, Z.H.; Zhi, Y.; Yang, Z.F. Crop planting pattern optimization for water scarcity alleviation in China. J. Ind. Ecol. 2016, 20, 435-445. [CrossRef]

12. Li, M.; Guo, P.; Singh, V.P. An efficient irrigation water allocation model under uncertainty. Agric. Syst. 2016, 144, 46-57. [CrossRef]

13. Singh, A. An overview of the optimization modelling applications. J. Hydrol. 2012, 466-467, 167-182. [CrossRef]

14. Cui, L.; Li, Y.P.; Huang, G.H. Planning an Agricultural Water Resources Management System: A Two-Stage Stochastic Fractional Programming Model. Sustainability 2015, 7, 9846-9863. [CrossRef]

15. Huang, Y.; Li, Y.P.; Chen, X.; Ma, Y.G. Optimization of the irrigation water resources for agricultural sustainability in Tarim River Basin, China. Agric. Water Manag. 2012, 107, 74-85. [CrossRef]

16. Li, M.; Guo, P. A multi-objective optimal allocation model for irrigation water resources under multiple uncertainties. Appl. Math. Model. 2014, 38, 4897-4911. [CrossRef]

17. Li, M.; Guo, P. A coupled random fuzzy two-stage programming model for crop area optimization-A case study of the middle Heihe River basin, China. Agric. Water Manag. 2015, 155, 53-66. [CrossRef]

18. Garg, N.K.; Dadhich, S.M. Integrated non-linear model for optimal cropping pattern and irrigation scheduling under deficit irrigation. Agric. Water Manag. 2014, 140, 1-13. [CrossRef]

19. Zhao, C.S.; Xia, J.; Li, Z.L.; Liu, Y.; Tang, B.H.; Tang, R.L.; Yan, Z.Q.; Ouyang, X.Y. Using high-temporal geostationary satellite data to analysis temporal and spatial pattern of regional water consumption-A case study of the agricultural district upstream the Bengbu Sluice in the Huaihe River Basin in spring drought season. J. Nat. Resour. 2008, 6, 1055-1067. [CrossRef]

20. Cai, J.L.; Varis, O.; Yin, H. China's water resources vulnerability: A spatio-temporal analysis during 2003-2013. J. Clean. Prod. 2017, 142, 2901-2910. [CrossRef]

21. He, R.Y.; Jin, Y.F.; Kandelous, M.M.; Zaccaria, D.; Sanden, B.L.; Snyder, R.L.; Jiang, J.B.; Hopmans, J.W. Evapotranspiration estimate over an almond orchard using Landsat satellite observations. Remote Sens. 2017, 9, 436. [CrossRef]

22. Multsch, S.; Grabowski, D.; Lüdering, J.; Alquwaizany, A.S.; Lehnert, K.; Frede, H.-G.; Winker, P.; Breuer, L. A practical planning software program for desalination in agriculture-SPARE: WATER ${ }^{\text {opt }}$. Desalination 2017, 404, 121-131. [CrossRef] 
23. Sethi, L.N.; Panda, S.N.; Nayak, M.K. Optimal crop planning and water resources allocation in a coastal groundwater basin, Orissa, India. Agric. Water Manag. 2006, 83, 209-220. [CrossRef]

24. Brown, P.D.; Cochrane, T.A.; Krom, T.D. Optimal on-farm irrigation scheduling with a seasonal water limit using simulated annealing. Agric. Water Manag. 2010, 97, 892-900. [CrossRef]

25. Zhang, Y.J.; Wang, Y.F.; Niu, H.S. Spatio-temporal variations in the areas suitable for the cultivation of rice and maize in China under future climate scenarios. Sci. Total Environ. 2017, 601-602, 518-531. [CrossRef] [PubMed]

26. Pietrucha-Urbanik, K. Multidimensional comparative analysis of water infrastructures differentiation. In Proceedings of the Conference on Environmental Engineering IV, Lublin, Poland, 03-05 September 2012; pp. 29-34. [CrossRef]

27. Pietrucha-Urbanik, K. Assessing the Costs of Losses Incurred as a Result of Failure. In Proceedings of the 11th International Conference on Dependability and Complex Systems (DepCoS-RELCOMEX), Brunow, Poland, 27 June-01 July 2016; pp. 355-362. [CrossRef]

28. Tchorzewska-Cieslak, B.; Rak, J. Method of identification of operational states of water supply system. In Proceedings of the 3rd Congress of Environmental Engineering, Lublin, Poland, 13-16 September 2019; pp. 521-526. [CrossRef]

29. Pietrucha-Urbanik, K.; Tchorzewska-Cieslak, B. Water Supply System operation regarding consumer safety using Kohonen neural network. In Proceedings of the 22nd Annual Conference on European Safety and Reliability (ESREL), Amsterdam, Netherlands, 29 September-2 October 2013; pp. 1115-1120.

30. Abah, R.C.; Petja, B.M. Crop suitability mapping for rice, Cassava, and Yam in North Central Nigeria. J. Agric. Sci. 2017, 9, 96-108. [CrossRef]

31. Piikki, K.; Winowiecki, L.; Vågen, T.G.; Ramirez-Villegas, J.; Söderström, M. Improvement of spatial modelling of crop suitability using a new digital soil map of Tanzania. S. Afr. J. Plant Soil 2017, 34, 243-254. [CrossRef]

32. Bittelli, M. Measuring Soil Water Potential for Water Management in Agriculture: A Review. Sustainability 2010, 2, 1226-1251. [CrossRef]

33. Li, J.; Zhu, T.; Mao, X.M.; Adeloye, A.J. Modeling crop water consumption and water productivity in the middle reaches of Heihe River Basin. Comput. Electron. Agr. 2016, 123, 242-255. [CrossRef]

34. Allen, R.G.; Pereira, L.S.; Raes, D.; Smith, M. Crop Evaporation: Guidelines for Computing Crop Water Requirements; Irrigation and Drainage Paper No. 56; Food and Agriculture Organization of the United Nations: Rome, Italy, 1998.

35. Lei, N.; Xie, Z.K.; Ma, Z.M. The research on water requirement of spring wheat and corn in Heihe Areas. In The Study on Crop Water Requirement and Water Saving Irrigation in Arid Areas; Li, S.Q., Lan, N.J., Eds.; Gansu Science and Technology Press: Lanzhou, China, 1992; pp. 25-34, (In Chinese). ISBN 7-5424-0428-8.

36. Chen, T.; Ren, L.L.; Yuan, F.; Yang, X.L.; Jiang, S.H.; Tang, T.T.; Liu, Y.; Zhao, C.X.; Zhang, L.M. Comparison of Spatial Interpolation Schemes for Rainfall Data and Application in Hydrological Modeling. Water 2017, 9 , 342. [CrossRef]

37. Fang, S.B.; Jia, R.F.; Tu, W.R.; Sun, Z.L. Assessing factors driving the change of irrigation water-use efficiency in China based on geographical features. Water 2017, 9, 759. [CrossRef]

38. Zhong, B.; Yang, A.X.; Wu, S.L.; Li, J.; Zeng, Y.L.; Liu, Q.H.; Zhao, J.; Xu, B.D. HiWATER: 1km/5day compositing Vegetation Index (NDVI/EVI) product of Heihe River Basin. Cold and Arid Regions Science Data Center at Lanzhou. 2014. [CrossRef]

39. Li, X.; Liu, S.M.; Xiao, Q.; Ma, M.G.; Jin, R.; Che, T.; Wang, W.Z.; Hu, X.L.; Xu, Z.W.; Wen, J.G.; et al. A multiscale dataset for understanding complex eco-hydrological processes in a heterogeneous oasis system. Sci. Data 2017, 4, 170083. [CrossRef] [PubMed]

40. Ouyang, Z.Y.; Weisman, J.; Wang, R.S. Ecological niche suitability model with an application in Taojiang land use planning. J. Environ. Sci. 1994, 6, 449-456.

41. Singh, R.B.; Chauhan, C.P.S.; Minhas, P.S. Water production functions of wheat (Triticum aestivum L.) irrigated with saline and alkali waters using double-line source sprinkler system. Agric. Water Manag. 2009, 96, 736-744. [CrossRef]

42. Liu, W.Z.; Hunsaker, D.J.; Li, Y.S.; Xie, X.Q.; Wall, G.W. Interrelations of yield, evapotranspiration, and water use efficiency from marginal analysis of water production functions. Agric. Water Manag. 2002, 56, 143-151. [CrossRef] 
43. Jiang, P.H.; Zhao, R.F.; Zhao, H.L.; Fan, J.P.; Wang, J.Z.; Liu, C. Spatial-Temporal Evolution of Land Use/Cover Change in Middle Section of Heihe Basin since 1975. J. Ecol. Rural Environ. 2012, 28, 473-479, (In Chinese with English Abstract). [CrossRef]

44. Li, Q.S.; Zhao, W.Z. Effect of Water Allocation of the Heihe River on Plan Structure and Stable Development of the Ecosystem in the Linze Oasis, Gansu-A Case Study in the Pingchuan Irrigation District in Linze County at the middle reaches of the Heihe River. J. Glaciol. Geocryol. 2004, 3, 333-343, (In Chinese with English Abstract). [CrossRef]

45. Tan, M.H.; Zheng, L.Q. Different irrigation water requirements of seed corn and filed corn in the Heihe River Basin. Water 2017, 9, 66. [CrossRef]

46. Tu, J.J.; Hua, J. An evaluation on farmland eco-economical suitability in mountain area based on niche fitness model and GIS technology. Chinese High Technology Letters. 2013, 4, 436-441, (In Chinese with English Abstract). [CrossRef]

47. Mao, L.X.; Zhao, J.F.; Xu, L.L.; Yan, H.; Li, S.; Li, Y.F. Climatic suitability of spring maize planted in the "sickle bend" area of China and regulation suggestion. Chin. J. Appl. Ecol. 2016, 27, 3935-3943. [CrossRef]

(C) 2018 by the authors. Licensee MDPI, Basel, Switzerland. This article is an open access article distributed under the terms and conditions of the Creative Commons Attribution (CC BY) license (http:/ / creativecommons.org/licenses/by/4.0/). 